\title{
PELAKSANAAN OTONOMI DESA DALAM MEWUJUDKAN PEMBERDAYAAN APARATUR PEMERINTAH DESA TAMBISKI NAULI, KECAMATAN NAGA JUANG KABUPATEN MANDAILING NATAL
}

\author{
Irman Puansah ${ }^{(1}$, Soritua Ritonga ${ }^{(2}$ \\ Universitas Muhammadiyah Tapanuli Selatan \\ irman.puansah@um-tapsel.ac.id ${ }^{1}$ \\ soritua.ritonga@um-tapsel.ac.id ${ }^{2}$
}

\begin{abstract}
Abstrak
Pelaksanaan otonomi desa di beberapa daerah masih belum berjalan sesuai dengan Undang-undang Nomor 6 Tahun 2014 Tentang Desa. Minimnya pemahaman Kepala desa, aparatur pemerintah desa dan Badan Permusyawaratan Desa mengakibatkan status otonom yang dimiliki desa tidak memberikan dampak yang signifikan terhadap kesejahteraan masyarakat meskipun telah dibarengi dengan dana desa yang cukup besar. Penelitian ini bertujuan untuk mengetahui bagaimana pelaksanaan otonomi desa di Desa Tambiski Nauli, Kecamatan Naga Juang Kabupaten Mandailing Natal dan untuk mengetahui bagaimana pemberdayaan aparatur pemerintah Desa Tambiski Nauli, Kecamatan Naga Juang Kabupaten Mandailing Natal. Adapun metode yang digunakan dalam penelitian ini adalah penelitian kualitatif dengan pendekatan deskriptif-analitis. Dari penelitian yang dilakukan diperoleh kesimpulan antara lain pelaksanaan otonomi desa di Desa Tambiski Nauli, Kecamatan Naga Juang Kabupaten Mandailing Natal belum berjalan sebagai mana mestinya. Kepala Desa, Aparatur pemerintah Desa dan Badan Permusyawaratan Desa belum memahami seutuhnya bagaimana penyelenggaraan Pemerintahan Desa berdasarkan asas Otonomi Desa dan Aparatur pemerintah Desa Tambiski Nauli, Kecamatan Naga Juang Kabupaten Mandailing Natal belum terberdayakan secara maksimal, aparatur pemerintah desa belum memahami akan tugas dan fungsinya sesuai dengan aturan yang berlaku.
\end{abstract}

Kata Kunci : Otonomi Desa, Pemberdayaan Aparatur, Pemerintah Desa

\begin{abstract}
The implementation of village autonomy in several regions has not yet proceeded according to Law No. 6 of 2014 concerning Villages. The lack of understanding of the village head, village government officials and the Village Consultative Body resulted in the autonomous status of the village does not have a significant impact on the welfare of the community even though it has been accompanied by a substantial village fund. This study aims to determine how the implementation of village autonomy in Tambiski Nauli Village, Naga Juang District Mandailing Natal District and to find out how empowerment of the government apparatus of Tambiski Nauli Village, Naga Juang District Mandailing Natal District. The method used in this research is qualitative research with a descriptive-analytical approach. From the research conducted, it can be concluded that the implementation of village autonomy in Tambiski Nauli Village, Naga Juang District, Mandailing Natal District has not been running properly. Village Head, Village Government Apparatus and Village Consultative Agency do not fully understand how the implementation of Village Government based on the principle of Village Autonomy and Village Government Apparatus Tambiski Nauli Village, Naga Juang Subdistrict Mandailing Natal Regency has not been fully empowered, the village government apparatus does not yet understand its tasks and functions in accordance with applicable rules.
\end{abstract}

Keywords: Village Autonomy, Empowerment of Personnel, Village Government 


\section{PENDAHULUAN}

Desa merupakan wilayah terkecil dalam kerangka Negara Kesatuan Republik Indonesia, desa juga sebagai daerah otonom terkecil di antara wilayah-wilayah lain yang ada di Indonesia, yaitu lebih kecil dari daerah otonom wilayah provinsi dan juga Kabupaten/Kota. Moh. Fadli, dalam bukunya yang berjudul Pembentukan Peraturan Desa Partisipatif (Head To Good Village overnance), menyebutkan bahwa "Desa menjadi bagian vital yang tidak dapat dipisahkan dalam hierarki struktur bernegara, karena pada hakikatnya tidak akan ada suatu negara tanpa memiliki bagian-bagian terkecil yang dalam konteks negara Indonesia biasa disebut desa. (Moh. Fadli, 2013,3).

Dalam konteks ini dapat dimaknai bahwa desa merupakan bagaian vital yang harus dikelola melalui pemerintahan desa yang baik, pemerintahan desa yang memiliki kewenangan untuk mengatur, mengelola desa tersebut. Dengan diberikannya hak politik dan dan hak administrasi, sesungguhnya desa bisa berkembang dan maju sesuai kebutuhan masyarkat setempat. Sebelum adanya otonomi desa, sesungguhnya desa melalui kepala desa hanya menjalankan yang sifatnya administratif saja. Namun begitu otonomi desa diberikan desa tidak hanya menjalankan secara administratif saja, akan tetapi memiliki kewenangan lebih dalam mengatur dan mengelola tersebut, serta dapat mengeluarkan kebijakan untuk kemaslahatan dan kemakmuran masyarakatnya.

Kedudukan pemerintahan desa yang bersifat otonom, yaitu berwenang untuk mengatur urusan rumah tangganya sendiri dalam perkembangannya sebagai turunan dari UUD NRI 1945 diatur dengan beberapa undang-undang. Mulai dari Undang-Undang No. 22 Tahun 1948 tentang Penetapan Aturan-Aturan Pokok Mengenai Pemerintahan Sendiri Di DaerahDaerah Yang Berhak Mengatur Dan Mengurus Rumah Tangganya Sendiri, Undang-Undang No. 19 Tahun 1965 tentang Desa praja Sebagai Bentuk Peralihan Untuk Mempercepat Terwujudnya Daerah Tingkat III Di Seluruh Wilayah Republik Indonesia pada masa
Orde Lama, Undang-Undang No. 5 Tahun 1979 tentang Pemerintahan Desa pada masa Orde Baru, Undang- Undang No. 22 Tahun 1999 tentang Pemerintahan Daerah dan Undang- Undang No. 32 Tahnn 2004 tentang Pemerintahan Daerah pada masa Reformasi, hingga yang terbaru adalah Undang-Undang No. 6 Tahun 2014 tentang Desa.

Menurut Pasal 1 Ayat 1 UndangUndang Nomor 6 Tahun 2014 tentang Desa. Desa adalah desa dan desa adat atau yang disebut dengan nama lain selanjutnya disebut Desa, adalah kesatuan masyarakat hukum yang memiliki batas wilayah yang berwenang megatur dan mengurus pemerintahan, kepentingan masyarakat, kepentingan masyarakat setempat berdasarkan prakarsa masyarakat, hak asal-usul dan atau hak tradisional yang diakui dan dihormati dalam sistem pemerintahan Negara Republik Indonesia.

Menurut Undang-Undang No. 6 Tahun 2014 tentang Desa Pasal 18 Kewenangan Desa meliputi kewengan di bidang penyelenggaraan Pemerintahan Desa, pelaksanaan pembangunan Desa, pembangunan kemasyarakatan Desa, dan pemberdayaan masyarakat Desa berdasarkan prakarsa masyarakat, hak, asal usul dan adat istiadat Desa dan menurut Pasal 19 kewenangan Desa meliputi :

1. Kewenangan berdasarkan hak asal usul;

2. Kewenangan lokal berskala Desa;

3. Kewenangan yang ditugaskan oleh pemerintah, pemerintah daerah, provinsi atau, Pemerintah Daerah Kabupaten atau Kota; dan

4. Kewenangan lain yang ditugaskan oleh Pemerintah, Pemerintah Daerah provinsi, atau Pemerintah Daerah Kabupaten atau Kota sesuai dengan ketentuan peraturan perundangundangan

$$
\text { Penyelenggaraan pemerintahan }
$$

desa juga dibantu oleh Badan Permusyawaratan Desa yang merupakan wakil dari penduduk desa berdasarkan keterwakilan wilayah yang pengisinya dilakukan secara demokratis. Badan Permusyawaratan Desa mempunyai tugas 
membahas dan menyempakati Rancangan Peraturan Desa bersama Kepala Desa selain menampung dan menyalurkan aspirasi masyarakat Desa juga melakukan pengawasan kinerja Kepala Desa. (Zuhraini.2016:235)

Dengan otonomi desa saat ini, sesungguhnya mengarahkan agar desadesa yang berada di seluruh Indonesia tidak lagi memiliki ketergantungan yang mutlak terhadap Pemerintah Pusat, Pemerintah Provinsi, Kabupaten dan juga Pemerintah Kota. Akan tetapai mampu menjalakan aktifitas pemerintahan dan pemberdayaan masyarakat secara mandiri. Untuk mewujudkan otonomi desa itu sendiri, mewujudkan desa yang mandiri sesungguhnya telah dibarengai dengan turunnya dana desa yang dikeluarkan dari APBN dengan besaran kurang lebih satu milyar, yang pengelolaannya dibebaskan kepada pemerintahan desa yang bersangkutan dengan aturan yang berlaku.

Meskipun demikian besar harapan kepada pemerintah desa agar tidak bergantung lagi dengan pusat secara berlebihan, kemudian dibarengan dengan pendanaan yang cukup besar, akan tetapi pelaksanaan otonomi desa sesungguhnya belum dapat dipahami secara baik oleh Pemerintah desa dan juga aparatur desanya. Dengan kata lain masih terdapat kepala desa begitu juga dengan aparat desa yang belum paham akan tugas dan fungsinya masing-masing, struktur organisasinya sesungguhnya telah jelas akan tetapi bagaimana aplikasi dari struktur tersebut tidak jalan.

Desa Tambiski misalnya, salah satu desa yang berada di Kecamatan Naga Juang Kabupaten Mandailing Natal Provinsi Sumatera Utara, yang merupakan lokasi penelitian ini. Desa tambiski dengan jumlah kepala keluarga 120, yang berdiri sejak tahun 2009 dengan rata-rata dana desa yang diperoleh sebesar kurang lebih 600 juta pertahunnya sejak dikeluarkannya dana desa. Hingga saat ini menurut penulis pemahaman terhadap otonomi desa oleh aparaturnya di desa tersebut belum juga dimaknai secara baik, sehingga pada pelaksanaannya masih belum baik juga, hal ini berakibat pada pelayanan terhadap masyarakat, pemberdayaan masyarakat serta kesejahteraan masyarakat akat sulit tercapai.

Kurangnya pemahaman aparatur pemerintahan di Desa Tambiski Nauli, hal ini ditandai beberapa hal:

1. Kurangnya Pemahaman terhadap tugas dan fungsi pada bidang masing-masing. Hal ini dapat dilihat pada Pemerintah desa dan Badan Permusyawaratan Desa. Pemerintah desa misalnya, Kepala desa beserta perangkatnya untuk melakukan rencana pembanggunan desa masih terbengkala oleh kemampuan yang tidak optimal. Dengan kata lain untuk membuat rencana pembangunan desa masih kesulitan dan terkadang masih meminta bantuan pihak luar agar tidak terjadi kesalahan. Begitu juga ketika akan membuat laporan desa, Pemerintah desa juga tidak paham dan masih meminta bantuan dari luar. (Keterangan Satia Muda/Kepdes). Kemudian Badan Permusyawaratan Desa juga demikian, hingga saat ini Badan Permusyawaratan Desa sangat jarang sekali melakukan musyawarah antar warga, padahal musyawarah sangat dibutuhkan untuk kesejahtraan masyarakat setempat. Lain hal lagi bahwa Badan Permusyawaratan Desa hingga saat ini belum pernah mengeluarkan peraturan desa, satu peraturan sekalipun.

2. Pelaksanaan pemerintahan tidak profesional dan akuntabel, hal ini didasari karena aparatur pemerintahan desa tidak memahami kapasitas masingmasing. baik Kepala Desa beserta perangkatnya dan juga Badan Permusyaratan Desa.

3. Pembentukan dan pelaksanaan Badan Usaha Milik Desa masih kesulitan, bahkan tidak mengetahui apa yang akan dilakukan, dan masyarakatpun belum diajak untuk musyawarah dalam hal tersebut.

4. Apabila kepala desa sedang berada di luar, maka kegiatan administrasi berhenti, dengan alas an kepala desa tidak ditempat, sehingga tidak bias ditanda tangani.

Dari beberapa indikasi masalah tersebut diatas dapat menunjukkan bahwa Implementasi otonomi desa dalam 
mewujudkan pemberdayaan aparatur pemerintah desa belum optimal, hal ini dikarenakan rendahnya faktor kemampuan aparatur pemerintah desa sehingga dalam penyelenggaraan tugas dan fungsi pemerintahan desa belum maksimal. Dengan demikian bahwa Aparat Pemerintah Desa adalah para penyelenggara pemerintahan di desa dalam rangka mengatur dan mengrus kepentingan masyarakat. Namun sejauh mana kebenaran indikasi masalah tersebut masih perlu dianalisis melalui suatu penelitian ilmiah.

Oleh karena itu, penulis merasa tertarik untuk melakukan penelitian dengan mengangkat judul penelitian: Pelaksanaan Otonomi Desa dalam Mewujudkan Pemberdayaan Aparatur Pemerintah Desa Tambiski Nauli, Kecamatan Naga Juang Kabupaten Mandailing Natal. Adapun tujuan penelitian ini adalah sebagai berikut:

1. Untuk mengetahui Bagaimana pelaksanaan otonomi desa di Desa Tambiski Nauli, Kecamatan Naga Juang Kabupaten Mandailing Natal.

2. Untuk mengetahui Bagaimana pemberdayaan aparatur Pemerintah desa Tambiski Nauli, Kecamatan Naga Juang Kabupaten Mandailing Natal.

\section{METODE}

Penelitian ini menggunakan Metode penelitian kualitatif, dimana menurut Sugiyono bahwa metode penelitian kualitatif adalah suatu metode penelitian ilmu-ilmu sosial yang mengumpulkan dan menganalisis data berupa kata-kata (lisan maupun tulisan) dan perbuatan-perbuatan manusia. Peneliti tidak berusaha menghitung atau mengkuantifikasikan data kualitatif yang telah diperoleh dan dengan demikian tidak menganalisis angka-angka. (Sugiyono,2009:54)

Dalam penelitian ini digunakan pendekatan deskriptif-analitis, dimana penelitian deskriptif dimaksudkan untuk pengukuran yang cermat terhadap fenomena sosial tertentu, dimana peneliti mengembangkan konsep dan menganalisis fakta yang ada. Menurut Muhammad Idrus, metode deskriptif diartikan sebagai prosedur pemecahan masalah yang diselidiki dengan menggambarkan keadaan objek pada saat sekarang dan berdasarkan fakta-fakta sebagaimana adanya. (Muhammad Idrus,2009:135).

Teknik pengumpulan data mempunyai hubungan dengan masalah penelitian. Dalam penelitian ini teknik pengumpulan data yang digunakan adalah:

a. Wawancara mendalam (in-depth interview).

b. Observasi melalui penelitian lapangan, pengamatan dan pencatatan secara sistematik terhadap gejala yang tampak pada objek penelitian.

c. Studi dokumentasi. Sumber-sumber data yang digunakan, antara lain: penelusuran kepustakaan seperti perundang-undangan, dokumendokumen yang terkait dengan penelitian tersebut.

Menurut Miles dan Huberman dalam Sugiyono (2009:246), mengemukakan bahwa aktivitas dalam analisa kualitatif dilakukan secara interaktif dan berlangsung secara terus-menerus sampai tuntas, sehingga datanya sudah jenuh (interactive model analysis). Tahapan dalam analisis data ini yaitu:

1. Data Reduction (Reduksi Data).

2. Data Display (Penyajian Data).

3. Conclusion Drawing (Penarikan Kesimpulan).

\section{PEMBAHASAN}

Pelaksanaan Otonomi Desa Tambiski Nauli, Kecamatan Naga Juang Kabupaten Mandailing Natal.

Desa merupakan suatu wilayah pemerintahan yang terdekat dengan masyarakat dalam suatu negara, sehingga desa memiliki peranan penting dalam pembangunan Nasional. Untuk mendukung dan memaksimalkan peran tersebut sesungguhnya desa telah memiliki hak otonom, Otonomi Desa merupakan otonomi yang asli, bulat dan utuh jika dilihat dari aspek tradisi, adat istiadat dan hukum yang relatif mandiri. Menurut Widjaja Secara hitoris desa merupakan cikal bakal terbentuknya masyarakat politik dan pemerintahan di Indonesia jauh sebelum Negara dan bangsa ini terbentuk, struktur sosial jenis desa, masyarakat adat dan lain sebagainya telah menjadi institusi sosial 
yang mempunyai posisi yang sangat penting. Desa merupakan institusi yang otonom dengan tradisi, adat istiadat dan hukumnya sendiri serta relatif mandiri. Hal ini antara lain ditunjukan dengan tingkat keragaman yang tinggi membuat desa mungkin merupakan wujud bangsa yang paling kongkret. (HAW. Widjaja, 2003: 4).
Dengan
Otonomi
Desa

penyelanggaraan Pemerintahan Desa mestinya lebih maksimal dalam memberdayakan masyarakat, mensejahterakan masyarakat dan dalam mengatur seluruh sumber daya yang terdapat di desa termasuk bagaimana mengatur apartur Pemerintahan Desa untuk mengeluarkan segala potensi yang dimiliki dalam mensejahterakan masyarakat. Memaksimalkan sumbersumber ekonomi. Untuk mendukung pelaksanaan Otonomi Desa telah diterbitkannya Undang-undang Nomor 6 Tahun 2014 Tentang Desa yang menyatakan bahwa pengaturan desa berasaskan:

1. Rekognisi, yaitu pengakuan terhadap hak asal-usul;

2. Subsidiaritas, yaitu penetapan kewenangan berskala lokal dan pengambilan keputusan secara lokal untuk kepentingan masyarakat Desa;

3. Keberagaman, yaitu pengakuan dan penghormatan terhadap sistem nilai yang .berlaku di masyarakat desa, tetapi dengan tetap mengindahkan sistem nilai bersama dalam kehidupan berbangsa dan bernegara;

4. Kebersamaan, yaitu semangat untuk berperan aktif dan bekerja sama dengan prinsip saling menghargai antara kelembagaan di tingkat Desa dan unsur masyarakat Desa dalam membangun Desa;

5. Kegotongroyongan, yaitu kebiasaan saling tolong-menolong untuk membangun Desa;

6. Kekeluargaan, yaitu kebiasaan warga masyarakat Desa sebagai bagian dari satu kesatuan keluarga besar masyarakat Desa;

7. Musyawarah, yaitu proses pengambilan keputusan yang menyangkut kepentingan masyarakat Desa melalui diskusi dengan berbagai pihak yang berkepentingan;

8. Demokrasi,yaitu sistem pengorganisasian masyarakat Desa dalam suatu sistem pemerintahan yang dilakukan oleh masyarakat Desa serta keluhuran harkat dan martabat manusia sebagai makhluk Tuhan Yang Maha Esa diakui, ditata, dan dijamin;

9. Kemandirian, yaitu suatu proses yang dilakukan oleh Pemerintah Desa dan masyarakat Desa untuk melakukan suatu kegiatan dalam rangka memenuhi kebutuhannya dengan kemampuan sendiri;

10. Partisipasi, yaitu turut berperan aktif dalam suatu kegiatan;

11. Kesetaraan, yaitu kesamaan dalam kedudukan dan peran;

12. Pemberdayaan, yaitu upaya meningkatkan taraf hidup dan kesejahteraan masyarakat Desa melalui penetapan kebijakan, program, dan kegiatan yang sesuai dengan esensi masalah dan prioritas kebutuhan masyarakat Desa; dan

13. Keberlanjutan, yaitu suatu proses yang dilakukan secara terkoordinasi, terintegrasi, dan berkesinambungan dalam merencanakan dan melaksanakan program pembangunan Desa.

Dalam rangka pelaksanaan tugas mengatur dan mengurus tersebut setiap Desa di beri wewenang sebagai berikut:

1. Kewenangan yang sudah ada berdasarkan asal usul Desa;

2. Kewenangan yang oleh peraturan perundang-undangan yang berlaku belum dilaksanakan oleh Daerah atau Pemerintah Pusat.

3. Tugas Pembantuan dari pemerintah Pusat, Pemerintah Provinsi atau Pemerintah Kabupaten. (H. Rozali Abdullah,2002:61

Selain kewenangan-kewenangan pemerintahan desa sebagaimana disebutkan diatas dalam Undang-Undang Nomor 6 Tahun 2014 tentang Desa juga menjelaskan beberapa hal berkaitan dengan asas pengaturan dalam pemerintahan desa. Semula kewenangan desa menjadi bagian dari politik desentralisasi, yakni otonomi daerah, 
sekarang berubah menjadi asas rekognisi dan subsidiaritas. (Ni'matul Huda,2014: 213-214).

Dengan asas tersebut Pemerintah Desa sesungguhnya memiliki Kewenangan yang luas untuk mengatur segala potensi desa, dengan asas tersebut penyelenggaraan Pemerintah Desa hendaknya melahirkan kebijakan-kebjakan yang pro terhadap masyarakat, mampu melahirkan kebijakan-kebijakan terhadap pengelolaan sumber daya secara mandiri. Oleh karenanya Aparatur Pemerintah Desa mestinya memiliki potensi untuk memanfaatkan kewenangan yang dimiliki untuk mengatur dan mengelola sumbersumber ekonomi desa.

Kepala Desa beserta perangkat desa harus memahami secara jelas akan tugas serta fungsi masing-masing. Dengan Pemahaman akan tugas dan fungsi oleh Kepala Desa beserta perangkat desa akan menjadikan Penyelenggaraan Pemerintah Desa semakin baik karena telah didukunga dengan asas pengaturan yang telah diberikan melalui Undang-undang Nomor 6 Tahun 2014 tersebut. Selain Kepala Desa beserta perangkatnya, Badan Permusyawaran Desa juga mesti paham akan posisinya di Pemerintah Desa, dengan memahami posisinya dalam Pemerintah Desa akan menjadikan Badan Permusyawaratan Desa juga memahami tugas dan fungsinya. Dengan memahami posisi serta tugas dan fungsi antara Kepala Desa beserta perangkatnya denga Badan Permusyawaratan Desa akan menjadikan Pemerintahan desa seimbang.

Deddy Supriady menyebutkan bahwa Penyelenggaraan Pemerintah Desa merupakan subsistem dari sitem penyelenggaraan pemerintahan, sehingga Desa memiliki kewenangan untuk mengatur dan mengurus kepentingan masyarakatnya. Kepala Desa bertanggung jawab pada Badan Perwakilan Desa dan menyampaikan laporan pelaksanaan tugas tersebut kepada Bupati. (Deddy Supriady 2002:8)

Dari berbagai penjelasan tersebut di atas dapat dilihat bahwa hal tersebut jauh berbeda dengan yang terlaksana di Desa Tambiski Nauli Kecamatan Naga Juang Kabupaten Mandailing Natal. Pada dasarnya Kepala Desa dan Aparatur Pemerintahan Desa beserta Badan Permusyawaratan Desa Belum terlalu paham akan makna Otonomi Desa tersebut, sehingga pada penyelenggaraan Pemerintah Desa masih banyak yang tidak sesuai baik dari aspek kebijakan dan juga administratif. Pada penyelenggaraan Pemerintah Desa sesungguhnya jauh dari apa yang telah tertuang dalam Undangundang Nomor 6 Tahun 2014 Tentang Desa tersebut.

Untuk memaksimalkan sumbersumber ekonomi mestinya pemerintah desa dalam mengatur pemerintahan harus mengedapankan asas yang tertuang dalam Undang-undang Nomor 6 Tahun 2014 Tentang Desa. Namun dalam pengaturannya Desa Tambiski Nauli tidak mengedapankan asas tersebut sehingga dalam peyelenggaraan pemerintahan desa belum mengalami peningkatan sesuai dengan otonomi desa yang diharapkan dan pengelolaan sumber-sumber ekonomi masih belum mampu dikelola sesuai dengan kebutuhan masyarakat.

\section{Pemberdayaan Aparatur Pemerintahan Desa Tambiski Nauli Kecamatan Naga Juang Kabupaten Mandailing Natal.}

Dalam rangka memaksimalkan sumber-sumber ekonomi yang terdapat di desa dan untuk penyelenggaraan pemerintah desa yang lebih baik diperlukan aparatur pemerintah desa yang paham akan tugas dan fungsinya sebagai landasan dalam melaksanakan tanggung jawabnya sebagai aparatur pemerintah desa. Aparatur pemerintah desa harus benar-benar diberdayakan agar susuai dengan fungsinya masing-masing sehingga penyelenggaraan pemerintah desa semakin terarah dan tidak terjadi tumpang tindah antar sesama aparatur dan kepala desa. akan tetapi di desa tambiski nauli aparatur pemeritah desa belum diberdayakan secara maksimal hal ini dilihat dari Kepala Desa dan Aparatur Pemerintah Desa begitu juga dengan Badan Permusyawaratan Desa belum memahami akan tugas dan fungsinya masing-masing.

Aparatur Pemerintah Desa misalnya dalam melaksanakan tugasnya hanya menunggu perintah dari Kepala Desa tanpa 
mengatahui akan tugas dan fungsinya masing-masing. Hal ini senada dengan yang disampaikan oleh Ketua BPD Desa Tambiski Nauli "Sejauh ini Aparatur Pemerintah Desa belum memahami akan tugas dan fungsinya, dalam melaksanakan tugasnya para aparatur hanya menunuggu perintah dari Kepala Desa, apapun yang di perintah Kepala Desa apakah hal tersebut sesuai atau tidak sesuai dengan tugas dan fungsinya akan tetap dilaksanakan. Kemudian para aparatur terkadang mengerjakan tugas kaur yang lain tanpa ada koordinasi sebelumnya, dan yang cukup memprinhatinkan adalah seorang Bendahara Desa ternyata tidak pernah memegang uang kas, karena yang memegang uang kas adalah Kepala Desa".

Berdasarkan keterangan tersebut diketahui bahwa para aparatur Pemerintah Desa tidak mengerti akan tugas dan fungsinya. Hal yang sama juga disampaikan salah satu anggota BPD "Aparatur Pemerintahan desa belum memahami akan tugas dan fungsinya sehingga penyelenggaraan Pemerintah Desa hanya dilaksankan oleh Kepala Desa. Para aparatur Pemerintah Desa hanya melaksanakan apa saja yang diperintahkan oleh Kepala Desa. Hingga sampai saat ini sepengetahuan saya tugas dari aparatur Pemerintah desa hanya menandatangani saja".

Kemudian ketika dimintai keterangan dari salah satu Kaur yaitu Pemerintahan memberikan penjelasan "Saya Secara jujur tidak paham akan tugas serta fungsi sebagai Kaur Pemerintahan, dan kami tidak bernah disampaikan akan tugas dan fungsi oleh Kepala Desa, sementara ketika bimtek iyang dibahas adalah masalah anggaran dana desa. Saya hanya mengerjakan apa yang diperintahkan oleh Kepala Desa saja".

Dari keterangan tersebut dapat kita ketahui bahwa Aparatur Pemerintahan Desa tidak Memahami akan tugas dan fungsinya masing-masing. Begita juga dengan Badan Permusyawaratan Desa ternyata tidak begitu memahi akan posisinya dalam Pemerintahan Desa. Dari keterangan anggota BPD menjelaskan bahwa sebagai anggota BPD selama 3 tahun yang dikerjakan hanyalah rapat dan menandatangan $R A B$, yang mana $R A B$ yang ditandatangani tersebut juga tidak diketahui isinya. Dan anggota BPD tersebut tidak pernah menanyakan kenapa hal tersebut dilakukan.

Padahal tugas dan fungsi Kepela Desa beserta Aparatur Pemerintah Desa sudah tertuang dalam Peraturan Menteri Dalam Negeri Republik Indonesia Nomor 84 Tahun 2015 Tentang Susunan Organisasi dan Tata Kerja Pemerintah Desa antara lain:

Tugas dan Fungsi Kepala Desa:

(1) Kepala Desa berkedudukan sebagai Kepala Pemerintah Desa yang memimpin penyelenggaraan Pemerintahan Desa.

(2) Kepala Desa bertugas menyelenggarakan Pemerintahan Desa, pembangunan, melaksanakan kemasyarakatan, pembinaan pemberdayaan masyarakat. dan

(3) Untuk melaksanakan tugas sebagaimana dimaksud pada ayat (2) Kepala Desa memiliki fungsifungsi sebagai berikut:

a) Menyelenggarakan

Pemerintahan Desa, seperti tata praja Pemerintahan, penetapan peraturan di desa, pembinaan masalah pertanahan, pembinaan ketentraman dan ketertiban, melakukan upaya perlindungan masyarakat, administrasi kependudukan, dan penataan dan pengelolaan wilayah.

b) melaksanakan pembangunan, seperti pembangunan sarana prasarana perdesaan, dan pembangunan bidang pendidikan, kesehatann.

c) pembinaan kemasyarakatan, seperti pelaksanaan hak dan kewajiban masyarakat, partisipasi masyarakat, sosial budaya masyarakat, keagamaan, dan ketenagakerjaan.

d) pemberdayaan masyarakat, seperti tugas sosialisasi dan motivasi masyarakat di bidang budaya, ekonomi, politik, lingkungan hidup, 
pemberdayaan

keluarga,

pemuda, olahraga, dan karang taruna.

e) menjaga hubungan kemitraan dengan lembaga masyarakat dan lembaga lainnya

Tugas dan Fungsi Sekretaris Desa:

(1) Sekretaris Desa berkedudukan sebagai unsur pimpinan Sekretariat Desa.

(2) Sekretaris Desa bertugas membantu Kepala Desa dalam bidang administrasi pemerintahan.

(3) Untuk melaksanakan tugas sebagaimana yang dimaksud pada ayat (2), Sekretaris Desa mempunyai fungsi:

a) Melaksanakan urusan ketatausahaan seperti tata naskah, administrasi surat menyurat, arsip, dan ekspedisi.

b) Melaksanakan urusan umum seperti penataan administrasi perangkat desa, penyediaan prasarana perangkat desa dan kantor, penyiapan rapat, pengadministrasian aset, inventarisasi, perjalanan dinas, dan pelayanan umum.

c) Melaksanakan urusan keuangan seperti pengurusan administrasi keuangan, administrasi sumber-sumber pendapatan dan pengeluaran, verifikasi administrasi keuangan, dan admnistrasi penghasilan Kepala Desa, Perangkat Desa, BPD, dan lembaga pemerintahan desa lainnya.

d) Melaksanakan urusan perencanaan seperti menyusun rencana anggaran pendapatan dan belanja desa, menginventarisir data-data dalam rangka pembangunan, melakukan monitoring dan evaluasi program, serta penyusunan laporan.

Tugas dan Fungsi Kepala Urusan:

(1) Kepala urusan berkedudukan sebagai unsur staf sekretariat.
(2) Kepala urusan bertugas membantu Sekretaris Desa dalam urusan pelayanan administrasi pendukung pelaksanaan tugas-tugas pemerintahan.

(3) Untuk melaksanakan tugas kepala urusan mempunyai fungsi:

a) Kepala urusan tata usaha dan umum memiliki fungsi seperti melaksanakan urusan ketatausahaan seperti tata naskah, administrasi surat menyurat, arsip, dan ekspedisi, dan penataan administrasi perangkat desa, penyediaan prasarana perangkat desa dan kantor, penyiapan rapat, pengadministrasian aset, inventarisasi, perjalanan dinas, dan pelayanan umum.

b) Kepala urusan keuangan memiliki fungsi seperti melaksanakan urusan keuangan seperti pengurusan administrasi keuangan, administrasi sumber-sumber pendapatan dan pengeluaran, verifikasi administrasi keuangan, dan admnistrasi penghasilan Kepala Desa, Perangkat Desa, BPD, dan lembaga pemerintahan desa lainnya.

c) Kepala urusan perencanaan memiliki fungsi mengoordinasikan urusan perencanaan seperti menyusun rencana anggaran pendapatan dan belanja desa, menginventarisir data-data dalam rangka pembangunan, melakukan monitoring dan evaluasi program, serta penyusunan laporan.

Tugas dan Fungsi Kepala Seksi:

(1) Kepala seksi berkedudukan sebagai unsur pelaksana teknis.

(2) Kepala seksi bertugas membantu Kepala Desa sebagai pelaksana tugas operasional.

(3) Untuk melaksanakan tugas Kepala Seksi mempunyai fungsi: 
a) Kepala seksi pemerintahan mempunyai fungsi melaksanakan manajemen tata praja Pemerintahan, menyusun rancangan regulasi desa, pembinaan masalah pertanahan, pembinaan ketentraman dan ketertiban, pelaksanaan upaya perlindungan masyarakat, kependudukan, penataan dan pengelolaan wilayah, serta pendataan dan pengelolaan Profil Desa.

b) Kepala seksi kesejahteraan mempunyai fungsi melaksanakan pembangunan sarana prasarana perdesaan, pembangunan bidang pendidikan, kesehatan, dan tugas sosialisasi serta motivasi masyarakat di bidang budaya, ekonomi, politik, lingkungan hidup, pemberdayaan keluarga, pemuda, olahraga, dan karang taruna.

c) Kepala seksi pelayanan memiliki fungsi melaksanakan penyuluhan dan motivasi terhadap pelaksanaan hak dan kewajiban masyarakat, meningkatkan upaya partisipasi masyarakat, pelestarian nilai sosial budaya masyarakat, keagamaan, dan ketenagakerjaan.

Berdasarkan Peraturan Menteri Dalam Negeri tersebut Kepala Desa dan Aparatur Pemerintahan Desa sudah memiliki tugas dan fungsi yang jelas, akan tetapi belum terlaksana secara maksimal. Sehingga tugas-tugas Pemerintah Desa lebih banyak dikerjakan oleh Kepala Desa dan tumpang tindih antara tugas kepala seksi masih sering terjadi. Selain dari pada itu ternyata antara Kepala Desa dan juga Badan Permusyawaratan Desa masih belum memahami secara utuh akan posisi serta tugas dan fungsinya masing-masing, sebagai salah satu contoh dalam tiga tahun berjalan Kepemimpinan Kepala Desa ternyata tidak sekalipun kepala desa melaporkan kinerja Kepada Badan Permusyawaratan Desa.

Berdasarkan Keterangan yang diperoleh dari berbagai informan bahwa Badan Permusyawaratan Desa saat ini yang dikerjakan hanyalah menandatangani RAB (Rencana Anggaran Biaya) saja, dan anggota Badan Permusyawaaratan Desa tidak mengetahui isi dari RAB tersebut. Kemudian yang dilakukan Badan Permusyawaratan Desa saaat ini yaitu menghadiri rapat-rapat desa. Badan Permusyawaratan Desa ternyata belum mampu menampung dan menyalurkan aspirasi dari masyarakat, hal tersebut dikarenakana berbagai keluhan dan keinginan masyarakat belum tersampaikan.

Padahal fungsi dari Badan Permusyawaratan Desa sudah jelas tertuang dalam Undang-undang Nomor 6 Tahun 2014 Tentang Desa pada pasal 55 yang berbunyi:

Badan Permusyawaratan Desa mempunyai fungsi:

a. Membahas dan menyepakati Rancangan Peraturan Desa bersama Kepala Desa;

b. Menampung dan menyalurkan aspirasi masyarakat Desa; dan

c. Melakukan pengawasan kinerja Kepala Desa.

Kepala Desa harus menyampaikan laporannya setiap akhir tahun tertuang dalam pasal 27 Undang-undang desa yang berbunyi. Dalam melaksanakan tugas, kewenangan, hak, dan kewajiban sebagaimana dimaksud dalam Pasal 26, Kepala Desa wajib:

a. Menyampaikan laporan penyelenggaraan Pemerintahan Desa setiap akhir tahun anggaran kepada Bupati/Walikota;

b. Menyampaikan laporan penyelenggaraan Pemerintahan Desa pada akhir masa jabatan kepada Bupati/Walikota;

c. Memberikan laporan keterangan penyelenggaraan pemerintahan secara tertulis kepada Badan Permusyawaratan Desa setiap akhir tahun anggaran; dan 
d. Memberikan dan/atau menyebarkan informasi penyelenggaraan pemerintahan secara tertulis kepada masyarakat Desa setiap akhir tahun anggaran.

Dari pembahasan tersebut dapat diketahui bahwa pada dasarnya Otonomi Desa belum berjalan maksimal di Desa Tambiski Nauli Kecamatan Naga Juang, hal tersebut ditandai dari pemahaman Kepala Desa, Aparatur Pemerintah Desa dan Badan Permusyawaratan Desa yang masih kurang terhadap penyelenggaraan Pemerintahan Desa yang Otonom, selain dari pada itu pemahaman yang masih minim terhadap tugas dan fungsi masingmasing menjadi salah satu tantangan bagi penyelenggaraan Pemerintahan Desa tersebut. Kepala Desa, BPD dan Aparatur Pemerintahan Desa belum terberdayakan secara maksimal padahal sudah memiliki tugas dan fungsi yang jelas.

Dari temuan dilapangan dan juga wawancara yang dilakukan bahwa terdapat beberapa faktor yang menyebabkan pemberdayaan Aparatur Pemerintah Desa tidak maksimal yang antara lain:

1. Sumber Daya Manusia Aparatur Pemerintahan Desa masih kurang.

2. Dominasi Kepala Desa dalam menjalankan Pemerintahan Desa dan tidak mampu memberikan arahan kepada aparatur Pemerintahan Desa.

3. Bimbingan teknis yang dilakukan oleh Pemerintah Daerah tidak maksimal.

4. Tidak berjalannya fungsi dari Badan Pemberdayaan Masyarakat.

5. Lemahnya Partisipasi Masyarakat.

\section{SIMPULAN DAN SARAN KESIMPULAN}

Dari pembahsan di atas diperoleh kesimpulan sebagai berikut:

1. Pelaksanaan otonomi desa di Desa Tambiski Nauli, Kecamatan Naga Juang Kabupaten Mandailing Natal belum berjalan sebagai mana mestinya. Kepala Desa, Aparatur Pemerintahan Desa dan Badan Permusyawaratan Desa belum memahami seutuhnya bagaimana penyelenggaraan Pemerintahan Desa berdasarkan asas Otonomi Desa.
2. Aparatur Pemerintah desa Tambiski Nauli, Kecamatan Naga Juang Kabupaten Mandailing Natal belum terberdayakan secara maksimal. Aparatur pemerintahan desa belum memahami akan tugas dan fungsinya sesuai dengan aturan yang berlaku. Aparatur Pemerintahan Desa hanya menunggu perrintah Kepala Desa untuk melaksanakan tugas-tugas desa.

\section{SARAN}

1. Diharapakan kepada Kepala Desa, Aparatur Pemerintahan Desa dan Badan Permusyawaratan Desa agar berupaya memahami bagaimana penyelenggaraan Pemerintahan Desa berdasarkan asas otonom, dengan mengkaji dan menelaah kembali Undang-undang Nomor 6 Tahun 2014 Tentang Desa dan melakukan berbagai kegiatan seperti workshop untuk menunjang kemampuan dalam memahami dan melaksankan otonomi desa.

2. Diharapakan kepada Kepala Desa agar berupaya memberdayakan Aparatur Pemerintahan Desa dengan menunjukkan tugas dan fungsi masingmasing serta memperkecil dominasi terhadap pelaksanaan penyelenggaraan Pemerintahan Desa terutama pada urusan-urusan yang seharusnya dilaksanakan oleh Aparatur Pemerintahan Desa.

\section{DAFTAR PUSTAKA}

Abdullah, H. Rozali, 2002, Pelaksanaan Otonomi Luas dan Isu federalisme sebagai suatu alternatif, $\quad \mathrm{Pt} \quad$ Rajagrafindo persada, Jakarta.

Fadli, Moh, Jazim Hamidi, 2013, dan Mustafa Lutfi, Pembentukan Peraturan Desa Partisipatif (Head To Good Village overnance), UB Press, Malang.

Huda, Ni'matul, 2014, Perkembangan Hukum Tata Negara Perdebatan 
dan Gagasan Penyempurnaan, FH UII Press, Yogyakarta.

Idrus, Muhammad, 2009, Metode Penelitian IImu Sosial Pendekatan Kualitatif dan Kuantitatif, Penerbit Erlangga, Jakarta.

Sugiyono. 2009. Metode Penelitian Pendidikan Pendekatan Kuantitatif, Kualitatif, dan R\&D. Bandung: Alfabeta.

Supriady, Deddy, 2002, Otonomi Penyelenggaraan Pemerintahan Daerah, Cetakan ketiga, PT Gramedia Pustaka Utama, Jakarta.

Widjaja, HAW, 2003, Otonomi Desa merupakan Otonomi Yang Asli, Bulat dan Utuh, Raja Grafindo Persada, Jakarta.

Zuhraini, 2016, Hukum Pemerintahan Desa, Fakultas Syariah IAIN Raden Intan Lampung.

\section{Peraturan Perundang-undangan:}

Undang-Undang No. 6 Tahun 2014 tentang Desa.

Peraturan Menteri Dalam Negeri Republik Indonesia Nomor 84 Tahun 2015 Tentang Susunan Organisasi Dan Tata Kerja Pemerintah Desa 